\title{
DETERMINANTS OF ACADEMIC FRAUD IN HIGHER EDUCATION INSTITUTIONS: A FRAUD TRIANGLE PERSPECTIVE
}

\author{
Kamaruzzaman Muhammad and Erlane K Ghani* \\ Faculty of Accountancy, Universiti Teknologi MARA Selangor, Malaysia \\ Muhammad Asyraf Haziq Rossli \\ Institute of Professional Studies, Kolej Universiti Poly-Tech MARA, Bangi, Malaysia \\ *Corresponding Author: erlanekg@uitm.edu.my
}

\begin{abstract}
This study examines the factors influencing academic fraud based on two components of the fraud triangle theory in a faculty of a university from the perspective of students. Specifically, this study examine whether pressure and opportunity increase the students' propensity to commit academic fraud. Using questionnaire survey on 227 respondents, this study shows a positive relationship between pressure and academic fraud. Among the reasons for the presence of pressure are wanting to help a friend, not likely to get caught, assessment being too difficult and pressure to get good grades. This study also shows a positive relationship between opportunity and academic fraud. Among the reasons are little or no discussion in class on academic fraud with specific examples and explanations of the consequences and, little or no reference being made to the University's policy on academic fraud in the syllabus and, students do not sign a statement that their work is their own. The findings of this study may enhance the readers understanding toward the relationship between the variables. This is imperative for a university especially the management to consider academic fraud as a serious issue. It is hope that the faculty can devise appropriate policies and procedures or improve its existing system to minimise the instance of academic fraud in the future, as well as meeting its organisational goals.
\end{abstract}

Keywords: Academic fraud, cheating, opportunity, pressure, university

Article Received: 10 August 2020, Revised: 25 October 2020, Accepted: 18 November 2020

\section{INTRODUCTION}

The incidence of academic fraud is a worldwide phenomenon, it is predominant and ever increasing in academia. This can be seen from the report published by Transparency International which discuss corruption in education, one of which is academic misconduct (Transparency International, 2013). For example, the report estimated that 600 out of approximately 25,000 people who receive a doctoral degree in Germany have used undue means.Malaysia too, is not an exception to academic fraud. According to a study, cheating in test and assignment can be seen as a serious threat as $65.3 \%$ of the respondents are classified as cheaters(Ismail \& Yussof, 2016). Furthermore, these cheaters who admitted to having cheated in examinations have a significantly greater tendency to justify their cheating action.

In recent years, one of the professional accounting courses, ACCA has shifted majority of its exam from paper-based to computer-based. As an approved learning provider, a university has been awarded access to computer-based exam practice platform which allows the faculty of the university design tests and assignments that mimic the live exam environment. Through 
the use of the technology, the faculty should not underestimate the possibility of academic fraud. However, previous studies have emphasised higher importance on the effect that technology contributes to cheating (Boyle, Boyle \& Carpenter, 2017).Therefore, it is imperative for the university to improve its system by understanding the relationship between pressure, opportunity and academic fraud. Through this, the university can evaluate possible measures to deter cheating, with a particular focus on the students that have enrolled for professional course.

This study aims to examine the factors influencing academic fraud based on two components of the fraud triangle theory, namely pressure and opportunity in a faculty of a university from the perspective of students. Specifically, this study examines whether pressure and opportunity increase the students' propensity to commit academic fraud. The findings of this study can provide some understanding on the relationship between pressure, opportunity and academic fraud and subsequently, allow the faculty of a university to devise appropriate policies to mitigate academic fraud. The remainder of this paper is organised as follows. Section 2 proceeds to reviews related literature. This is followed by research design in Section 3. The empirical results and discussions are presented in Section 4. The final section concludes the paper which includes suggestions for future research.

\section{LITERATURE REVIEW}

Fraud is an act of deception and consists seven elements which are; it is a representation; that relates to a material point; in which it is actually false; and it is intentional or reckless; to which the victim believes; and it is done on the victim; that leads to damage to the victim (Albrecht, Albrecht, Albrecht \& Zimbelman, 2012). There have been reports that organisations lost about $5 \%$ of their annual revenues to fraud with a known losses of more than USD 7.1 billion (ACFE, 2018). It is believed that this number alone is a tiny fraction of frauds committed against organisations globally, with the true costs likely to be on a different scale higher than what is being reported. Thus, it is adequate to justify that fraud is a global issue that needs to be looked into and addressed.

The threat to fraud does not resides in businesses alike as this threat also persists in academic environment. Academic fraud refers to actions, behaviours or, in some cases, omissions that may give rise to an inappropriate assessment of an individual's academic performance or which give an unfair advantage to some individuals in their educational endeavours (Bujaki, Lento, \& Sayed, 2019). Academic fraud is further classified into two categories, academic dishonesty and research misconduct (Walker \& Holtfreter, 2015).

Numerous studies have provided various definition to academic dishonesty. The first relates to student's actions that violate the explicit rules or norms for academic activities including examinations or assignments (Nahar, 2019). Another study defined it as actions that result in breaches of proper assessment on the assessment or grades (Eastman, Eastman \& Iyer, 2008). However, they all share the same concept namely, cheating.Cheating on exams has been a widespread phenomenon in the world regardless of the levels of detection development. Several instances of cheating use prewritten sheets which usually in small font hidden in clothes, under wrist watch or books, using devices to communicate answers, continuing to write after the exam's time has expired and gaining unauthorised access to test material before writing (Bujaki et al, 2019; Griffin, Bolkan \& Goodboy, 2015). The incidence of cheating is a serious threat that can be seen in prior studies where $65.3 \%$ of the respondents were classified as cheaters and even more disturbing when the cheaters who admitted to having cheated in examinations have a significantly greater tendency to justify their cheating action (Ismail \& Yussof, 2016).

On the other hand, research misconduct refers to activities that specifically relates to research. It connotes the concept of fabrication, falsification, or plagiarism in proposing, performing, or 
reviewing research, or in reporting research results (US Office of Science and Technology Policy, 2000). Research misconduct involves activities such as plagiarism, misuse of research grants and falsifying data as well as outcomes of research.A recent study identified various sources of research misconduct and classified them into four types according to its nature of behaviour which are: data manipulation; use of work by others; use of own work; and authorship (Hall \& Martin, 2019. Research conduct is categorised as whether it is being appropriate, questionable, inappropriate or blatant misconduct. A few examples of blatant misconduct are data fabrication, data falsification and plagiarism.

In the context of academia, the concept of fraud triangle theory can provide a better understanding on the factors contributing to academic fraud. The fraud triangle theory which was introduced by Donald Cressey in 1953 designated three elements as necessary for white-collar crime to take place; pressure, opportunity and rationalisation (Schuchter \& Levi, 2013). Pressure refers to the motivation behind the crime which the offender considers it as unshareable with others whom may be able to offer assistance. Opportunity to commit fraud refers to a stage where individual sees a clear course of action by which they can abuse their position to solve the perceived unshareable problem which they thought is unlikely to be discovered. Rationalization refers to the ability to neutralise the crime and this is the final stage in the fraud triangle. The fraudster tends to be able to justify the crime or improper act in a way that is acceptable to his or her internal moral compass (Schuchter \& Levi, 2013).

The Fraud Triangle theory can also be applied in the academic environment. A study summarized prior studies on various causes for academic fraud, organized by the elements of the fraud triangle(Tinkelman, 2009).Factors that contributes to incentives or pressures in academic fraud includes the pressure to score a good grade in order to meet parents' expectation, meeting job demands and to secure financial aid. Other factors may include pressure on top students to maintain success, peer or social pressure, individuals that suffers from test anxiety, procrastination that leaves little time for preparation, and fear of failure. The pressure component within the fraud triangle is capable of influencing students' susceptibility to cheat in the class (Choo\& Tan, 2015). Past studies highlighted grades were such a concern for the students as they represent majority of students' reasons for deception (Boyle, Boyle \& Carpenter, 2017). This form of pressure to score a good grade is mainly due to meeting parents' expectation, meeting the job demands and to secure financial aid.

Another form of pressure is impression management concerns, where students mentioned they used deception to avoid an awkward interaction or save face (Boyle, Boyle \& Carpenter, 2017). This indicates that students' tend to pretend that they are good students or to avoid offending an instructor. In this instance, students noted that their reason for using deception reflected a need to present themselves positively to others. Although earlier studies have indicated that pressure plays a role in students' decision to engage in cheating behaviour, another study suggested that students appear to have a subjective threshold in the cheating behaviour (Amigud \& Lancaster, 2019). It is not the factors that are influencing cheating, but rather how they are perceived by an individual at a certain moment in time. Students do not intend to cheat but, once they reached their threshold, they are not willing to continue and decides to cheat. These past findings lead to the following hypothesis:

H1: The presence of pressure will increase the students' propensity to commit academic fraud.

In relation to opportunity, the factors that lead to opportunity to commit academic fraud includes the use of technology that allows storing or communicating information, availability of online resources to plagiarise one's work, the chance of getting caught is small as the faculty rarely enforce codes, as well as repetitive or similar forms of questions or assignments being 
used by the faculty. The factors than can influence academic fraud can be determined by using the fraud triangle theory under the element of opportunity. This can be seen from past studies which indicates that the presence of opportunities will significantly increase the students' propensity to cheat (Choo\& Tan, 2015).

In recent years, the growing use of technologies in academia has also witnessed rapid developments to academic fraud. Technology has vastly increased students' perceived opportunity to use other people's work on papers and projects. Students can cut and paste material easily from the internet, and they can also buy ready-made or custom made assignments. Past study places higher importance on the effect that technology contributes to cheating (Boyle, Boyle \& Carpenter, 2017).

Another study which focused on opportunity to collaborate or utilize unauthorized resources during unmonitored assessments, investigates the deterrent effect of Webcam-based proctoring on misconduct during online exams (Hylton, Levy \& Dringus, 2016). This environment provides greater levels of opportunity to engage in misconduct compared to those who were monitored by a Web-based proctor.These past findings lead to the following hypothesis:

$\mathrm{H} 2$ : The presence of opportunity will increase the students' propensity to commit academic fraud.

\section{RESEARCH DESIGN}

\subsection{Sample}

This study chooses the students in a faculty of a university as the sample study. In 2019, there were currently 617 students that enrolled in the faculty of the university. The target population for this study are 541 students who registered for July until December 2019 session as this study excludes students who are currently on leave or deferral status. The reason to exclude these students is solely based on the difficulty to get response. The sample size for this study is based on the published formula for determining sample size (Krejcie \& Morgan, 1970). That is, a population size of 550 would require at least 226 sample size, and therefore it is deemed appropriate.

\subsection{Research Instrument}

This study uses self-administered questionnaire which was adapted from prior studies. The questionnaire is divided into four sections. Section A entails questions relating to the respondents' demographic. Section B draws upon motivators (pressure) that would cause a student to engage in academic fraud whereas Section $\mathrm{C}$ focus on controls that would provide opportunity for student to engage in academic fraud. Finally, Section D deals with the types of academic fraud that occur in the university. In order to enhance the response rate, respondents were assured of strict confidentiality of the information they share with the researcher and that the information was to be used solely for research purposes.

\subsection{Data Collection Method}

The questionnaire was distributed online to all of the students who are currently registered for July until December 2019 session, in the faculty of the university. The questionnaire was distributed though the social media application which is "Whatsapp" and by doing this, primary data can be collected. Due to budget constraint and benefit consideration, all the questionnaires were distributed through google forms. Google forms provide free service, which emulates an online survey system. The respondents can access easily these questionnaires using their smart gadgets or personal computers as long as they are connected to the internet.

\section{RESULTS}

\subsection{Descriptive Analysis}

The descriptive analysis assessed the distribution data across demographic characteristics of respondents which are the respondents' semester, age, gender, race and qualification held. Table 1 until 5 show how the respondents were distributed according to the selected demographic characteristics. Table 1 shows that most of the respondents were between semester 2 to semester 4 , comprising of $92.6 \%$. 
Table 1: Frequency of respondents' semester

\begin{tabular}{|c|c|c|c|c|c|}
\hline \multicolumn{2}{|c|}{ Semester of respondents } & Frequency & Percent & Valid Percent & Cumulative Percent \\
\hline Valid & Semester 1 & 5 & 2.2 & 2.2 & 2.2 \\
\cline { 2 - 6 } & Semester 2 & 68 & 30.0 & 30.0 & 32.2 \\
\cline { 2 - 6 } & Semester 3 & 64 & 28.2 & 28.2 & 60.4 \\
\cline { 2 - 6 } & Semester 4 & 78 & 34.4 & 34.4 & 94.7 \\
\cline { 2 - 6 } & Semester 5 & 4 & 1.8 & 1.8 & 96.5 \\
\cline { 2 - 6 } & Semester 6 onwards & 8 & 3.5 & 3.5 & 100.0 \\
\cline { 2 - 6 } & Total & 227 & 100.0 & 100.0 & \\
\hline
\end{tabular}

Table 2 shows that majority of the students are in the age between 18 to 22 years old. There are 23 to 26 , two students between the age of 27 to only three students that fall between the age of

30 , and a student that is above 30 years old.

Table 2: Frequency of respondents' age

\begin{tabular}{|c|c|c|c|c|c|}
\hline \multicolumn{2}{|c|}{ Age of respondents } & Frequency & Percent & Valid Percent & Cumulative Percent \\
\hline Valid & 18 to 22 years old & 221 & 97.4 & 97.4 & 97.4 \\
\cline { 2 - 6 } & 23 to 26 years old & 3 & 1.3 & 1.3 & 98.7 \\
\cline { 2 - 6 } & 27 to 30 years old & 2 & .9 & .9 & 99.6 \\
\cline { 2 - 6 } & Above 30 years old & 1 & .4 & .4 & 100.0 \\
\cline { 2 - 6 } & Total & 227 & 100.0 & 100.0 & \\
\hline
\end{tabular}

Table 3 shows that the students are represented almost equally in both gender categories with

$47.6 \%$ being male and $52.4 \%$ being female.

Table 3: Frequency of respondents' gender

\begin{tabular}{|c|c|c|c|c|c|}
\hline \multicolumn{2}{|c|}{ Gender of respondents } & Frequency & Percent & Valid Percent & Cumulative Percent \\
\hline Valid & Male & 108 & 47.6 & 47.6 & 47.6 \\
\cline { 2 - 6 } & Female & 119 & 52.4 & 52.4 & 100.0 \\
\cline { 2 - 6 } & Total & 227 & 100.0 & 100.0 & \\
\hline
\end{tabular}

Table 4 shows that the students sampled only fall into two categories. This indicates that Chinese and Indian students are not covered in

this study. Hence, the generalisation from this study is only valid for students' population who are Malays and others categories.

Table 4: Frequency of respondents' race

\begin{tabular}{|c|c|c|c|c|c|}
\hline \multicolumn{2}{|c|}{ Race of respondents } & Frequency & Percent & Valid Percent & Cumulative Percent \\
\hline Valid & Malay & 221 & 97.4 & 97.4 & 97.4 \\
\cline { 2 - 6 } & Others & 6 & 2.6 & 2.6 & 100.0 \\
\cline { 2 - 6 } & Total & 227 & 100.0 & 100.0 & \\
\hline
\end{tabular}

Table 5 shows that majority of the students hold graduates, degree holders and professional either a diploma or equivalent qualification. The certificate holders. This study does not cover rest of the sampled students are high school students who hold master or PhD qualification.

Table 5: Frequency of respondents' qualification

\begin{tabular}{|c|c|c|c|c|c|}
\hline \multicolumn{2}{|c|}{ Qualification of respondents } & Frequency & Percent & Valid Percent & Cumulative Percent \\
\hline Valid & $\begin{array}{c}\text { High School Graduate } \\
\text { (eg SPM, IGCSE) }\end{array}$ & 24 & 10.6 & 10.6 & 10.6 \\
\hline
\end{tabular}




\begin{tabular}{|c|c|c|c|c|c|}
\hline \multirow{4}{*}{$\begin{array}{c}\text { Diploma or Equivalent } \\
\text { (eg CAT) }\end{array}$} & 199 & 87.7 & 87.7 & 98.2 \\
\cline { 2 - 5 } & Degree & 2 & .9 & .9 & 99.1 \\
\cline { 2 - 6 } & $\begin{array}{c}\text { Professional certification } \\
\text { (eg ACCA, ICSA) }\end{array}$ & 2 & .9 & .9 & 100.0 \\
\cline { 2 - 6 } & Total & 227 & 100.0 & 100.0 & \\
\hline
\end{tabular}

\subsection{Normality Test}

Test of normality was carried out in order to assess whether there is violation of assumption that relates to normal distribution. The Kolmogorov-Smirnov test was used to compare the scores in the sample and the results are shown in Table 6. Results from the table show that all of the scores are non-normal. This can be seen from, taking an example, copying from another student on a test, $D(227)=0.270, p<$
0.001 , shows a score that deviates significantly from normal. A significant value of less than 0.05 suggests a violation in the assumption of normality.

In large samples, the K-S test can be significant even when the scores are only slightly different from a normal distribution. Therefore, this study looks at another indicators for normality which are skew and kurtosis.

Table 6: Tests of Normality

\begin{tabular}{|c|c|c|c|c|c|c|}
\hline & \multicolumn{3}{|c|}{ Kolmogorov-Smirnov $^{\mathrm{a}}$} & \multicolumn{3}{c|}{ Shapiro-Wilk } \\
\cline { 2 - 7 } & Statistic & $\mathrm{df}$ & Sig. & Statistic & df & Sig. \\
\hline Copying from another student on a test & .270 & 227 & .000 & .851 & 227 & .000 \\
\hline Using unauthorised material during a test & .281 & 227 & .000 & .870 & 227 & .000 \\
\hline $\begin{array}{c}\text { Continuing to write after the test time has } \\
\text { expired }\end{array}$ & .266 & 227 & .000 & .856 & 227 & .000 \\
\hline Communicating by signals during a test & .195 & 227 & .000 & .899 & 227 & .000 \\
\hline $\begin{array}{c}\text { Gaining unauthorised access to test material } \\
\text { before writing }\end{array}$ & .188 & 227 & .000 & .914 & 227 & .000 \\
\hline $\begin{array}{c}\text { Getting someone else to pretend they are } \\
\text { the student (impersonation) during a test }\end{array}$ & .231 & 227 & .000 & .838 & 227 & .000 \\
\hline $\begin{array}{c}\text { Using washroom breaks to access } \\
\text { unauthorized materials }\end{array}$ & .165 & 227 & .000 & .901 & 227 & .000 \\
\hline $\begin{array}{c}\text { Requesting special consideration/ deferred } \\
\text { exam assuming that the conditions are not } \\
\text { genuinely met }\end{array}$ & .194 & 227 & .000 & .914 & 227 & .000 \\
\hline $\begin{array}{c}\text { Having another person complete an } \\
\text { assignment or using another student's } \\
\text { assignment from a previous semester }\end{array}$ & .208 & 227 & .000 & .892 & 227 & .000 \\
\hline
\end{tabular}

Table 7 shows that the score for "getting someone else to pretend they are the student (impersonation) during a test" of 0.928 is the most positively skewed which indicates a pile up of scores on the left of distribution, whereas "copying from another student on a test" shows a score of -0.876 being the most negatively skewed, indicates that scores are piled up on the right of distribution.

On the other hand, the score for "copying from another student on a test" of 0.358 is the most leptokurtic which indicates a heavy-tailed distribution as scores are more peaked than normal, whereas "using washroom breaks to access unauthorized materials" shows a score of -1.058 is the most platykurtic which indicates a light-tailed distribution of scores.

Data is considered to be normally distributed if the skewness and kurtosis is in the range of \pm 2.00 , and if the kurtosis is in the range of 
\pm 7.00 . Therefore, the survey results are deemed

assumption of normality.

normal and acceptable as they do not violate the

Table 7: Tests of Normality based on Skewness and Kurtosis

\begin{tabular}{|c|c|c|c|c|c|}
\hline \multirow{2}{*}{} & $\mathrm{N}$ & \multicolumn{2}{|c|}{ Skewness } & \multicolumn{2}{c|}{ Kurtosis } \\
\cline { 2 - 6 } & Statistic & Statistic & Std. Error & Statistic & Std. Error \\
\hline Copying from another student on a test & 227 & -.876 & .162 & .358 & .322 \\
\hline Using unauthorised material during a test & 227 & -.518 & .162 & -.780 & .322 \\
\hline $\begin{array}{c}\text { Continuing to write after the test time has } \\
\text { expired }\end{array}$ & 227 & -.743 & .162 & -.366 & .322 \\
\hline Communicating by signals during a test & 227 & -.337 & .162 & -.595 & .322 \\
\hline $\begin{array}{c}\text { Gaining unauthorised access to test } \\
\text { material before writing }\end{array}$ & 227 & -.091 & .162 & -.588 & .322 \\
\hline $\begin{array}{c}\text { Getting someone else to pretend they are } \\
\text { the student (impersonation) during a test }\end{array}$ & 227 & .928 & .162 & .322 & .322 \\
\hline $\begin{array}{c}\text { Using washroom breaks to access } \\
\text { unauthorized materials }\end{array}$ & 227 & -.171 & .162 & -1.058 & .322 \\
\hline $\begin{array}{c}\text { Requesting special consideration/deferred } \\
\text { exam assuming that the conditions are not } \\
\text { genuinely met }\end{array}$ & 227 & -.098 & .162 & -.548 & .322 \\
\hline $\begin{array}{c}\text { Having another person complete an } \\
\text { assignment or using another student's } \\
\text { assignment from a previous semester }\end{array}$ & 227 & -.482 & .162 & -.614 & .322 \\
\hline \begin{tabular}{c} 
Valid N (listwise) \\
\hline
\end{tabular} & 227 & & & & \\
\hline
\end{tabular}

\subsection{Reliability Analysis}

A reliability analysis was used to measure the consistency of a measure. Table 8 shows $\alpha$ of 0.675 which is slightly below the acceptable score, but it still indicates good reliability. From the Corrected Item-Total Correlation in Table 9 shows that all items correlate between each other except for "Assessment is too difficult" that shows a score of 0.176 . This potentially indicates questionable internal consistency and if this was to be taken out, it would increase the reliability to 0.686 which is slightly above the overall reliability score. However, the items on this subscale cover quite diverse themes of pressure which might explain the relative lack of consistency. Hence, no adjustment was made to take out the questionable scale.

Table 8: Reliability Test on Pressure

\begin{tabular}{|c|c|c|}
\hline Cronbach's Alpha & $\begin{array}{c}\text { Cronbach's Alpha Based on } \\
\text { Standardized Items }\end{array}$ & N of Items \\
\hline .675 & .681 & 8 \\
\hline
\end{tabular}

Table 9: Reliability Test - Total Statistics of Pressure

\begin{tabular}{|c|c|c|c|c|c|}
\hline & $\begin{array}{c}\text { Scale Mean if } \\
\text { Item Deleted }\end{array}$ & $\begin{array}{c}\text { Scale } \\
\text { Variance if } \\
\text { Item Deleted }\end{array}$ & $\begin{array}{c}\text { Corrected } \\
\text { Item-Total } \\
\text { Correlation }\end{array}$ & $\begin{array}{c}\text { Squared } \\
\text { Multiple } \\
\text { Correlation }\end{array}$ & $\begin{array}{c}\text { Cronbach's } \\
\text { Alpha if Item } \\
\text { Deleted }\end{array}$ \\
\hline Wanting to help a friend & 24.21 & 16.457 & .360 & .246 & .647 \\
\hline Not likely to get caught & 24.29 & 17.172 & .349 & .238 & .649 \\
\hline Assessment is too difficult & 24.08 & 18.525 & .176 & .271 & .686 \\
\hline Pressure to get good grades & 23.59 & 16.836 & .489 & .337 & .622 \\
\hline
\end{tabular}




\begin{tabular}{|c|c|c|c|c|c|}
\hline $\begin{array}{c}\text { Cheating is victimless /not } \\
\text { wrong }\end{array}$ & 25.61 & 15.859 & .378 & .242 & .643 \\
\hline $\begin{array}{c}\text { Assessment was too time } \\
\text { consuming }\end{array}$ & 24.56 & 16.168 & .412 & .363 & .633 \\
\hline $\begin{array}{c}\text { Test date or due date was too } \\
\text { close to other test/assignments }\end{array}$ & 24.21 & 16.103 & .505 & .291 & .613 \\
\hline $\begin{array}{c}\text { Teaching method did not } \\
\text { accommodate student's } \\
\text { learning style }\end{array}$ & 24.63 & 17.243 & .299 & .215 & .661 \\
\hline
\end{tabular}

Table 10 shows $\alpha$ of 0.681 which is slightly below the acceptable score, but it still indicates good reliability. From the Corrected Item-Total Correlation in Table 11 shows that all items correlate between each other except for three variables which are "Not changing assignments and exams each year in order to limit student's access to past materials"; "Not checking the washrooms before an exam for unauthorized materials"; and "Not using online resources, search engines or other plagiarism software to detect plagiarism", which shows a score of $0.263 ; 0.237$ and 0.238 respectively. Again, this potentially indicates questionable internal consistency. However, Cronbach's Alpha if Item Deleted indicates that none of the items in the table would increase the reliability if they were deleted because all values in this column are less than the overall reliability of 0.681 . Hence, no adjustment was made to take out the questionable scales.

Table 10: Reliability Test on Opportunity

\begin{tabular}{|c|c|c|}
\hline Cronbach's Alpha & $\begin{array}{c}\text { Cronbach's Alpha Based on } \\
\text { Standardized Items }\end{array}$ & N of Items \\
\hline .681 & .682 & 9 \\
\hline
\end{tabular}

Table 11: Reliability Test - Total Statistics of Opportunity

\begin{tabular}{|c|c|c|c|c|c|}
\hline & $\begin{array}{c}\text { Scale Mean if } \\
\text { Item Deleted }\end{array}$ & $\begin{array}{c}\text { Scale } \\
\text { Variance if } \\
\text { Item Deleted }\end{array}$ & $\begin{array}{c}\text { Corrected } \\
\text { Item-Total } \\
\text { Correlation }\end{array}$ & $\begin{array}{c}\text { Squared } \\
\text { Multiple } \\
\text { Correlation }\end{array}$ & $\begin{array}{c}\text { Cronbach's } \\
\text { Alpha if Item } \\
\text { Deleted }\end{array}$ \\
\hline $\begin{array}{c}\text { Little/no discussion in class } \\
\text { about academic fraud with } \\
\text { specific examples and } \\
\text { explanations of the consequences }\end{array}$ & 28.01 & 18.730 & .306 & .410 & .666 \\
\hline $\begin{array}{c}\text { Little/no reference made to the } \\
\text { University's policy on academic } \\
\text { fraud in the syllabus }\end{array}$ & 28.16 & 18.161 & .436 & .433 & .639 \\
\hline $\begin{array}{c}\text { Students do not sign a statement } \\
\text { that their work is their own }\end{array}$ & 28.09 & 17.447 & .471 & .324 & .629 \\
\hline $\begin{array}{c}\text { Not using multiple examination } \\
\text { versions }\end{array}$ & 28.15 & 17.314 & .523 & .402 & .619 \\
\hline $\begin{array}{c}\text { Not changing assignments and } \\
\text { exams each year in order to limit } \\
\text { student's access to past materials }\end{array}$ & 28.30 & 19.266 & .263 & .196 & .674 \\
\hline $\begin{array}{c}\text { Not checking the washrooms } \\
\text { before an exam for unauthorized } \\
\text { materials }\end{array}$ & 28.11 & 19.555 & .237 & .135 & .679 \\
\hline
\end{tabular}




\begin{tabular}{|c|c|c|c|c|c|}
\hline $\begin{array}{c}\text { Not creating assessment such that } \\
\text { the question responses are unique } \\
\text { to a student and cannot be copied }\end{array}$ & 27.87 & 18.572 & .412 & .274 & .644 \\
\hline $\begin{array}{c}\text { Not using online resources, } \\
\text { search engines or other } \\
\text { plagiarism software to detect } \\
\text { plagiarism }\end{array}$ & 28.03 & 19.986 & .238 & .174 & .677 \\
\hline $\begin{array}{c}\text { No/lower the certainty of } \\
\text { punishment if detected }\end{array}$ & 28.14 & 18.623 & .328 & .159 & .661 \\
\hline
\end{tabular}

Table 12 shows $\alpha$ of 0.797 which is certainly in the region of acceptable score, and probably indicates good reliability. From the Corrected Item-Total Correlation in Table 13 shows that all items correlate between each other except for two variables which are "Continuing to write after the test time has expired"; and "Getting someone else to pretend they are the student (impersonation) during a test", which shows a score of 0.280 and 0.274 respectively. Again, this potentially indicates questionable internal consistency. However, Cronbach's Alpha if Item Deleted indicates that both would result in $\alpha$ of 0.804 and 0.803 which is slightly above the overall reliability score of 0.797 and therefore immaterial. Hence, no adjustment was made to take out the questionable scales.

Table 12: Reliability Test on Academic Fraud

\begin{tabular}{|c|c|c|}
\hline Cronbach's Alpha & $\begin{array}{c}\text { Cronbach's Alpha Based on } \\
\text { Standardized Items }\end{array}$ & N of Items \\
\hline .797 & .796 & 9 \\
\hline
\end{tabular}

Table 13: Reliability Test - Total Statistics of Academic Fraud

\begin{tabular}{|c|c|c|c|c|c|}
\hline & $\begin{array}{c}\text { Scale Mean if } \\
\text { Item Deleted }\end{array}$ & $\begin{array}{c}\text { Scale } \\
\text { Variance if } \\
\text { Item Deleted }\end{array}$ & $\begin{array}{c}\text { Corrected } \\
\text { Item-Total } \\
\text { Correlation }\end{array}$ & $\begin{array}{c}\text { Squared } \\
\text { Multiple } \\
\text { Correlation }\end{array}$ & $\begin{array}{c}\text { Cronbach's } \\
\text { Alpha if Item } \\
\text { Deleted }\end{array}$ \\
\hline $\begin{array}{c}\text { Copying from another student on } \\
\text { a test }\end{array}$ & 25.07 & 35.376 & .443 & .326 & .783 \\
\hline $\begin{array}{c}\text { Using unauthorised material } \\
\text { during a test }\end{array}$ & 25.33 & 34.374 & .466 & .402 & .780 \\
\hline $\begin{array}{c}\text { Continuing to write after the test } \\
\text { time has expired }\end{array}$ & 24.98 & 36.960 & .280 & .325 & .804 \\
\hline $\begin{array}{c}\text { Communicating by signals } \\
\text { during a test }\end{array}$ & 25.44 & 31.512 & .701 & .519 & .747 \\
\hline $\begin{array}{c}\text { Gaining unauthorised access to } \\
\text { test material before writing }\end{array}$ & 25.59 & 33.047 & .623 & .470 & .759 \\
\hline $\begin{array}{c}\text { Getting someone else to pretend } \\
\text { they are the student } \\
\text { (impersonation) during a test }\end{array}$ & 26.56 & 37.407 & .274 & .180 & .803 \\
\hline $\begin{array}{c}\text { Using washroom breaks to } \\
\text { access unauthorized materials }\end{array}$ & 25.56 & 31.991 & .577 & .468 & .764 \\
\hline $\begin{array}{c}\text { Requesting special } \\
\text { consideration/deferred exam } \\
\text { assuming that the conditions are } \\
\text { not genuinely met }\end{array}$ & 25.66 & 34.491 & .525 & .462 & .773 \\
\hline
\end{tabular}




\begin{tabular}{|c|c|c|c|c|c|}
\hline $\begin{array}{l}\text { Having another person complete } \\
\text { an assignment or using another } \\
\text { student's assignment from a } \\
\text { previous semester }\end{array}$ & 25.24 & 33.715 & .510 & .367 & .774 \\
\hline $\begin{array}{l}\text { In sum, the incidence of academ } \\
\text { high reliability, Cronbach's } \alpha= \\
\text { both the pressure and oppo } \\
\text { acceptable reliability, Cronbacl }\end{array}$ & $\alpha=0.6$ & \multicolumn{4}{|c|}{$\begin{array}{l}\text { Table } 14 \text { shows overall reliability for all } \\
\text { variables, Cronbach's } \alpha=0.779 \text { which is } \\
\text { certainly in the region of acceptable score, and } \\
\text { probably indicates good reliability. }\end{array}$} \\
\hline
\end{tabular}

Table 14: Reliability Test on All Variables

\begin{tabular}{|c|c|c|}
\hline Cronbach's Alpha & $\begin{array}{c}\text { Cronbach's Alpha Based on } \\
\text { Standardized Items }\end{array}$ & N of Items \\
\hline .779 & .777 & 26 \\
\hline
\end{tabular}

\subsection{Correlation BetweenPressure And} Academic Fraud

Table 15 shows the correlation between pressure (IV1) and academic fraud (DV). A statistical significant relationship exist when $p<0.05$,

therefore there is a positive relationship between pressure and academic fraud, $r=0.16, p=0.02$. This indicates that the presence of pressure will increase the students' propensity to commit academic fraud.

Table 15: Correlation Results

\begin{tabular}{|c|c|c|c|}
\hline \multirow{3}{*}{ Pressure } & Pressure & Academic Fraud \\
\hline \multirow{7}{*}{ Academic Fraud } & Pearson Correlation & 1 & $.161^{*}$ \\
\cline { 2 - 4 } & Sig. (2-tailed) & & .015 \\
\cline { 2 - 4 } & $\mathrm{N}$ & 227 & 227 \\
\cline { 2 - 4 } & Pearson Correlation & $.161^{*}$ & 1 \\
\cline { 2 - 4 } & Sig. (2-tailed) & .015 & 227 \\
\hline
\end{tabular}

\subsection{Correlation BetweenOpportunity And Academic Fraud}

Table16 shows the correlation between opportunity (IV2) and academic fraud (DV). A statistical significant relationship exist when $p^{<}$
0.05 , therefore there is a positive relationship between opportunity and academic fraud, $r=$ $0.16, p=0.02$. This indicates that the presence of opportunity will increase the students' propensity to commit academic fraud.

Table 16: Correlation Results

\begin{tabular}{|c|c|c|c|}
\hline \multirow{3}{*}{ Opportunity } & Pearson Correlation & Opportunity & Academic Fraud \\
\cline { 2 - 4 } & Sig. (2-tailed) & 1 & $.158^{*}$ \\
\cline { 2 - 4 } & $\mathrm{N}$ & 227 & .017 \\
\hline \multirow{3}{*}{ Academic Fraud } & Pearson Correlation & $.158^{*}$ & 227 \\
\cline { 2 - 4 } & Sig. (2-tailed) & .017 & 1 \\
\cline { 2 - 4 } & $\mathrm{N}$ & 227 & 227 \\
\hline
\end{tabular}

\subsection{Multiple Regression Analysis}

A formula was used for the calculation where sample size, $N>50+8 m$ (where $m$ is the number of independent variables)(Tabachnick\&Fidell, 2013). Hence, this study should have more than 45 or 66 respondents respectively based on the above recommendations. The survey respondents for this study are 227 which is sufficient to conduct the multiple regression analysis. 
Table 17: Model Summary of Multiple Regression Analysis

\begin{tabular}{|c|c|c|c|c|}
\hline Model & $\mathrm{R}$ & $\mathrm{R}$ Square & Adjusted R Square & Std. Error of the Estimate \\
\hline 1 & $.197^{\mathrm{a}}$ & .039 & .030 & .71212 \\
\hline \multicolumn{5}{|c|}{ a. Predictors: (Constant), Opportunity, Pressure } \\
\hline
\end{tabular}

Based on Table 17, the value of $\mathrm{R}^{2}$ is 0.039 . This shows that pressure and opportunity can account for $3.9 \%$ variation in academic fraud. This indicates that the remaining $96.1 \%$ of the variation in academic fraud remains unaccounted for which implies that there might be other variables that have an influence.

In this study, the null hypothesis is that the presence of pressure and opportunity will not increase the students' propensity to commit academic fraud. Based on Table 18 , the $F$ statistic is $4.534, p<0.05$, because the $p$-value is 0.012 , which is less than the significance level of 0.05 , shows that the null hypothesis can be rejected and concludes that the presence of pressure and opportunity will increase the students' propensity to commit academic fraud.

Table 18: Summary of ANOVA

\begin{tabular}{|c|c|c|c|c|c|c|}
\hline \multicolumn{2}{|c|}{ Model } & Sum of Squares & df & Mean Square & F & Sig. \\
\hline \multirow{8}{*}{1} & Regression & 4.599 & 2 & 2.299 & 4.534 & $.012^{\text {b }}$ \\
\cline { 2 - 7 } & Residual & 113.593 & 224 & .507 & & \\
\cline { 2 - 6 } & Total & 118.192 & 226 & & \\
\hline \multicolumn{7}{|c|}{ a. Dependent Variable: Academic Fraud } \\
\hline
\end{tabular}

Multiple regression is then tested for multicollinearity which refers to a strong correlation among the independent variables. Multiple regression shows no multicollinearity when the tolerance value is above 0.1 or a VIF which do not exceed 10 (Field, 2018; Pallant, 2016). Another guideline is if the average VIF is substantially greater than 1 , then the regression may be biased (Field, 2018). Based on table 19, the tolerance values are well above 0.1 and the VIF values are well below 10. The average VIF is $1.106[(1.106+1.106) / 2]$ which is slightly above 1 . Therefore, the regression in this study do not violate the assumption of multicollinearity. These results are not surprising, given that the Pearson correlation coefficient between these two independent variables was only 0.31 .

Another analysis made was to test the magnitude of the independent variables on the dependent variable, whether it is different from zero. For this study, the pressure variable, $t(224)=1.80$, $p>0.05$ and the opportunity variable, $t(224)=$ $1.74, p>0.05$, are both not significant predictors of academic fraud. In other words, from the magnitude of the $t$-statistics, the study concludes that both pressure and opportunity had less impact on academic fraud. This is supported by the standardised beta values for both pressure and opportunity of 0.124 and 0.120 respectively, further suggesting that both variables have a relatively smaller effect on academic fraud.

Table19: Coefficients ${ }^{\mathrm{a}}$ of Multiple Regression Analysis

\begin{tabular}{|c|c|c|c|c|c|c|c|c|}
\hline \multirow{2}{*}{ Model } & \multicolumn{2}{|c|}{$\begin{array}{c}\text { Unstandardized } \\
\text { Coefficients }\end{array}$} & $\begin{array}{c}\text { Standardized } \\
\text { Coefficients }\end{array}$ & \multirow{2}{*}{$\mathrm{t}$} & \multirow{2}{*}{ Sig. } & \multicolumn{2}{c|}{ Collinearity Statistics } \\
\cline { 3 - 9 } \cline { 6 - 9 } & B & Std. Error & Beta & & & Tolerance & VIF \\
\hline \multirow{2}{*}{1} & (Constant) & 2.066 & .376 & & 5.493 & .000 & & \\
\cline { 2 - 9 } & Pressure & .157 & .087 & .124 & 1.801 & .073 & .904 & 1.106 \\
\cline { 2 - 9 } & Opportunity & .164 & .094 & .120 & 1.737 & .084 & .904 & 1.106 \\
\hline
\end{tabular}


a. Dependent Variable: Academic Fraud

\subsection{Discussion}

This study shows that there is a positive relationship between pressure and academic fraud. Based on table 15, pressure has a $p$-value of 0.015 which is less than 0.05 . Therefore, $\mathrm{H}_{1}$ is accepted and the null hypothesis is rejected. However, results from table 19 suggests that pressure has a relatively small impact on academic fraud as it shows a $p$-value of 0.073 which is more than 0.05 , and a standardised beta value of 0.124 . On the other hand, table 16 shows that opportunity has a $p$-value of 0.017 which is less than 0.05 . This also indicates that there is a positive relationship between opportunity and academic fraud. Therefore, $\mathrm{H}_{2}$ is accepted and the null hypothesis is rejected. However, results from table 19 suggests that pressure has a relatively small impact on academic fraud as it shows a $p$-value of 0.084 which is more than 0.05 , and a standardised beta value of 0.120 .

The correlation is in line with previous studies in which pressure and opportunity does positively influence the instance of academic fraud [14]. However, the findings of this study leads to a conclusion that both pressure and opportunity have minimal impact on academic fraud although in a positive way. This may be due to the students' perception that academic fraud, such as cheating in the final exam conduct by ACCA worldwide may leads to a removal from the ACCA registry. As such, pressure may only exists internally within the college, perhaps in internal mock examination or tests. Therefore, students may participate in learning activities until they reach a certain subjective threshold at which they are not willing to continue their study and eventually would lead them to commit academic fraud [16].

The same could be said for opportunity, as the final exam is conducted elsewhere outside of college, the presence of invigilators appointed by the exam centre and high standard of regulations by ACCA serves as a safeguard from academic fraud by the professional body. This may suggest a lower impact of opportunity on academic fraud. Supposedly the positive relationship may exists internally within the college as the faculty is trying to replicate the live exam environment by ACCA within the college, but with a perception of less strict regulations.

\section{CONCLUSION}

This study examines the factors influencing academic fraud based on two components of fraud triangle which are pressure and opportunity in a faculty of a university from the perspective of students. Specifically, this study aims to examine whether pressure and opportunity increase the students' propensity to commit academic fraud. Based on the analysis of the data from 227 respondents, the following conclusions were made. First, this study concludes that there is a positive relationship between pressure and academic fraud. The presence of pressure was presented as a result of wanting to help a friend, it is not likely to get caught, assessment being too difficult, pressure to get good grades, the act of cheating is victimless or not wrong, assessment was too time consuming, the test date or due date was too close to other test or assignments, and the teaching method did not accommodate to student's learning style. All of this form of pressure will lead to student to commit academic fraud.

On the other hand, this study also concludes that there is a positive relationship between opportunity and academic fraud. The opportunity were presented as control deficiencies as a result of little or no discussion in class about academic fraud with specific examples and explanations of the consequences, little or no reference being made to the University's policy on academic fraud in the syllabus, students do not sign a statement that their work is their own, not using multiple version of examination, not changing assignments and exams each year in order to limit student's access to past materials, not checking the washrooms before an exam for unauthorized materials, not creating assessment 
such that the question responses are unique to a student and cannot be copied, not using online resources, search engines or other plagiarism software to detect plagiarism, and none or lower the certainty of punishment if detected. All of this form of opportunity will lead to student to commit academic fraud.Both of these factors correlate with academic fraud and is in line with past literature in which pressure and opportunity does positively influence the instance of academic fraud (Tinkelman, 2009). The study also concludes that both pressure and opportunity have minimal impact on academic fraud albeit the positive correlations.

This study is not without any limitations. Firstly, the data collected is solely based on students who are enrolled within the faculty of the university. Hence, the results are derived only from the viewpoint of professional students and does not consider the overall picture of a university. Secondly, as with most survey-based studies, this study is limited by general uncertainty regarding the linkage between students' reported perceptions and reality. For example, a student may perceive lack of search engines or other plagiarism software to detect plagiarism as an opportunity to act in academic fraud to exist, when, in reality, it is not since the students are under strict monitoring during the live exam.

Future studies are encouraged to employ data from various perspectives including student, faculty and administrator. As can be seen from this study and past literature, most studies focused on a single perspective rather than from multiple viewpoints. Combining multiple perspectives into a single study may result in better understanding on the factors that can influence academic fraud.Additionally, future research could expand the target population by collecting data from various faculties, or cross sectional studies over multiple universities. The rich data sets may further enhance the understanding on the factors that can impact academic fraud through comparison between multiple faculties or universities.

In sum, the outcome of this study may enhance the readers understanding toward the relationship between the variables. It is imperative for the college especially the management to consider academic fraud as a serious issue. Hopefully, the faculty can devise appropriate policies and procedures or improve its existing system to minimise the instance of academic fraud in the future, as well as meeting its organisational goals and its KPI.

\section{ACKNOWLEDGMENT}

We wish to thank the Research Management Centre of UniversitiTeknologi MARA for their support and funding.

\section{REFERENCES}

- Albrecht, W. S., Albrecht, C. 0., Albrecht, C. C., \& Zimbelman, M. F. (2012). Fraud Examination (4th ed.). South-Western College Pub.

- ACFE. (2018). 2018 Global Study on Occupational Fraud and Abuse. Retrieved from https://www.acfe.com/report-to-thenations/2018/default.aspx

- Amigud, A., \& Lancaster, T. (2019). 246 Reasons to Cheat: An Analysis of Students' Reasons for Seeking to Outsource Academic Work. Computers and Education, 134(January), 98-107. https://doi.org/10.1016/j.compedu.2019.01.0 17

- Boyle, D. M., Boyle, J. F., \& Carpenter, B. W. (2017). Accounting Student Academic Dishonesty: What Accounting Faculty and Administrators Believe. Accounting Educators' Journal, 26(2006), 39-61.

- Bujaki, M., Lento, C., \& Sayed, N. (2019). Utilizing Professional Accounting Concepts to Understand and Respond to Academic Dishonesty in Accounting Programs. Journal of Accounting Education, 47, 28-47.

- Choo, F., \& Tan, K. (2015). The Effect of Fraud Triangle Factors on Students' Cheating Behaviors. Advances in Accounting Education, 9, 205-220. 
- Eastman, K. L., Eastman, J. K., \& Iyer, R. (2008). Academic Dishonesty: An Exploratory Study Examining Whether Insurance Students are Different from Other College Students. Risk Management and Insurance Review, 11(1), 209-226.

- Field, A. (2018). Discovering Statistics Using IBM SPSS Statistics. In Sage Publications Ltd (5th ed.). Sage Publications Ltd

- Hall, J., \& Martin, B. R. (2019). Towards a Taxonomy of Research Misconduct: The Case of Business School Research. Research Policy, 48(2), 414-427

- Hylton, K., Levy, Y., \& Dringus, L. P. (2016). Utilizing Webcam-based Proctoring to Deter Misconduct in Online Exams. Computers and Education, 92-93, 53-63.

- Ismail, S., \& Yussof, S. H. (2016). Cheating Behaviour Among Accounting Students: Some Malaysian Evidence. Accounting Research Journal, 29(1), 20-33.

- Krejcie, R. V, \& Morgan, D. (1970). Determining Sample Size for Research Activities. Educational and Psychological Measurement, 30, 607-610

- Nahar, H. S. (2019). Academic Malaise Among Future Muslim Accountants: Role of
Piety. Journal of Islamic Accounting and Business Research, 10(3), 421-447

- Schuchter, A., \& Levi, M. (2013). The Fraud Triangle Revisited. Security Journal, 29(2), 107-121.

- Tabachnick, B. G., \& Fidell, L. S. (2013). Using Multivariate Statistics. In Contemporary Psychology: A Journal of Reviews (6th ed., Vol. 28). https://doi.org/10.1037/022267

- Tinkelman, D. (2009). Using Auditing Concepts to Discourage College Student Academic Misconduct and Encourage Engagement. Journal of Academic and Business Ethics, 1-28.

- Transparency International. (2013). Global Corruption Report: Education. In Global Corruption Report: Education. https://doi.org/10.4324/9780203109816

- US Office of Science and Technology Policy. (2000). Federal Research Misconduct Policy. Retrieved from https://ori.hhs.gov/federal-researchmisconduct-policy

- Walker, N., \& Holtfreter, K. (2015). Applying Criminological Theory to Academic Fraud. Journal of Financial Crime, 22(1), 48-62 